\title{
Ampullectomy of an unusual lesion developing 20 years after endoscopic treatment of a type III choledochocele
}

A type III choledochocele is a rare congenital cystic dilation of the intraduodenal portion of the main bile duct, representing $5 \%$ of all choledochal cysts according to the Toldani classification [1]. Choledochoceles may cause biliary obstruction and carcinoma development with a reported incidence of $2.5 \%$. To date, endoscopic treatment remains the less invasive technique, which consists of cystic mass removal associated with sphincterotomy [2,3]. However, the risk of carcinoma development may persist even after treatment and reports of longterm outcomes are lacking [4].

Herein we report the original case of a 78-year-old woman presenting with a previous history of sphincterotomy for a type III choledochocele 20 years ago ( $\triangleright$ Video 1$)$. She presented with a 12-mm low-grade dysplasia adenoma arising from the sphincterotomy scar ( Fig.1), mimicking an ampulloma. To the best of our knowledge, such a lesion has yet to be reported. Imaging modalities (endoscopic ultrasound and magnetic resonance imaging) revealed a $9-\mathrm{mm}$ moderate dilation of the main bile duct upstream of a distal stenosis (> Fig. 2).

A new endoscopic procedure was performed. The patient was placed in a dorsal position under general anesthesia. Similar to an ampullectomy, a duodenoscope under $\mathrm{CO} 2$ insufflation was used. An en bloc resection was performed using a $15-\mathrm{mm}$ braided snare (Lariat; Life Partners Europe, Bagnolet, France) and the specimen was immediately retrieved (>Fig.3). Cholangiography revealed a delayed clearance of the contrast due to the distal stenosis (> Fig.4). Complementary intraductal biopsies of the stenosis were performed using a pediatric biopsy forceps. Prevention of post-ampullectomy pancreatitis was ensured by intrarectal indometacine ad-

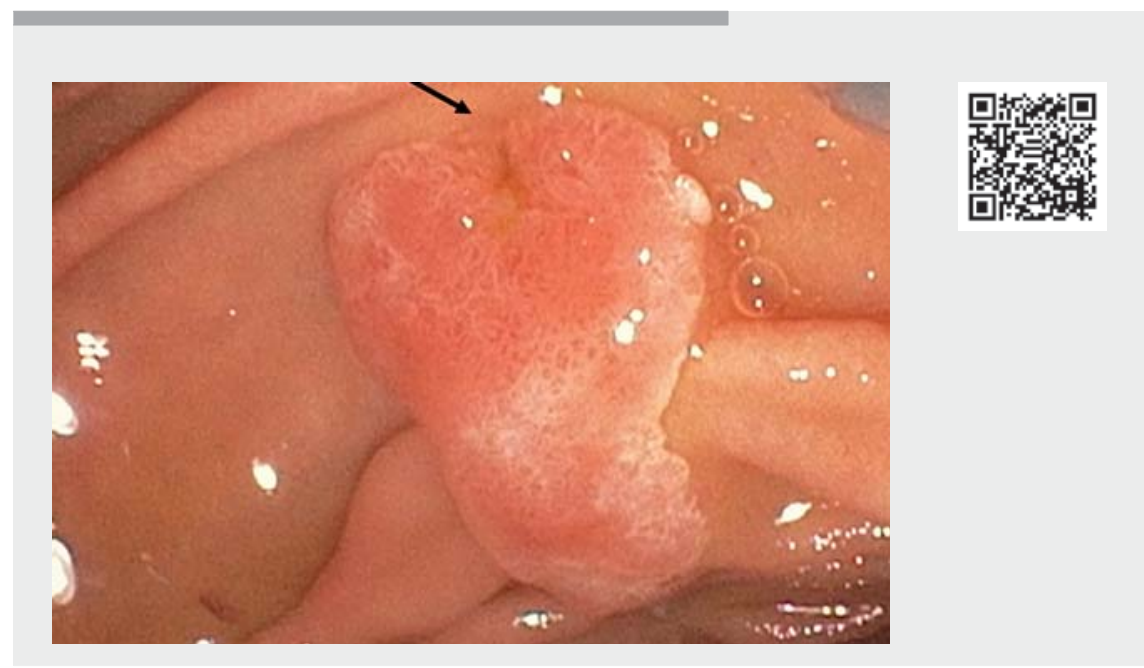

$\checkmark$ Video 1 Ampullectomy of an unusual lesion that developed 20 years after endoscopic treatment of a type III choledochocele.

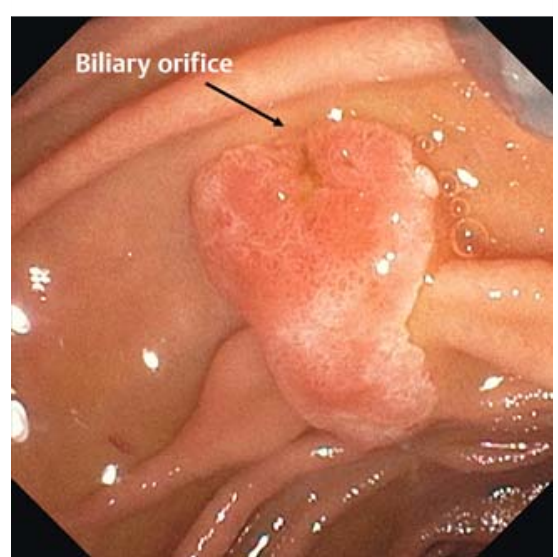

Fig. 1 Endoscopic view of the ampulloma-like lesion involving the biliary tract and the whole ampulloma mass.

ministration, pancreatic stenting with a $5-\mathrm{Fr} \times 5-\mathrm{cm}$ plastic stent, and ringer lactate hyperhydration. The patient was discharged after $24 \mathrm{~h}$ without complications.

Final histology confirmed the R0 resection of a low-grade dysplasia adenoma. Biopsies of the stenosis revealed only fi-

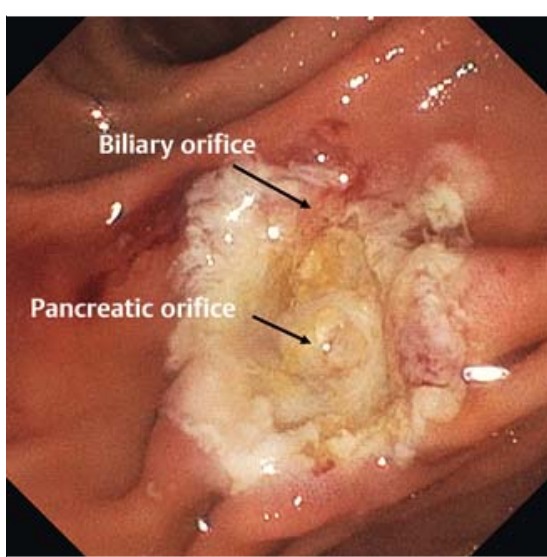

Fig. 2 Endoscopic aspect of the duodenal wall after resection.

brotic tissue. The 4-month follow-up duodenoscopy confirmed the absence of local recurrence.

Endoscopy_UCTN_Code_CCL_1AZ 


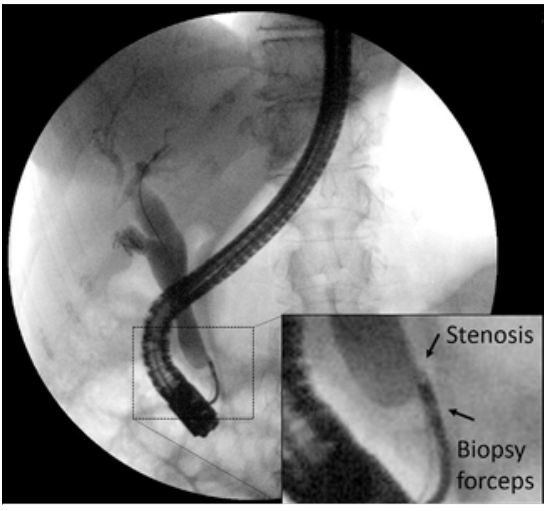

- Fig. 3 Additional biopsies of the stenosis were guided by cholangiography. Cholangiography revealed a distal stenosis of the main bile duct. Biopsy sampling of the stenosis was performed using pediatric biopsy forceps.

Competing interests

The authors declare that they have no conflict of interest.

The authors

Guillaume Perrod ${ }^{1} \oplus_{\text {, Ariane Vienne }}^{1}$, Enrique Pérez-Cuadrado-Robles ${ }^{1}$, Hedi Benosman', Chloé Broudin², Christophe Cellier ${ }^{1}$, Gabriel Rahmi $^{1}$

1 Gastroenterology and Digestive Endoscopy Department, Georges Pompidou European Hospital, Paris, France

2 Pathology Department, Georges Pompidou European Hospital, Paris, France

Corresponding author

\section{Dr Guillaume Perrod, MD}

Gastroenterology and Digestive Endoscopy Department, Georges Pompidou European Hospital, AP-HP.Centre Université de Paris, 20 Rue Leblanc, 75015 Paris, France guillaume.perrod@aphp.fr

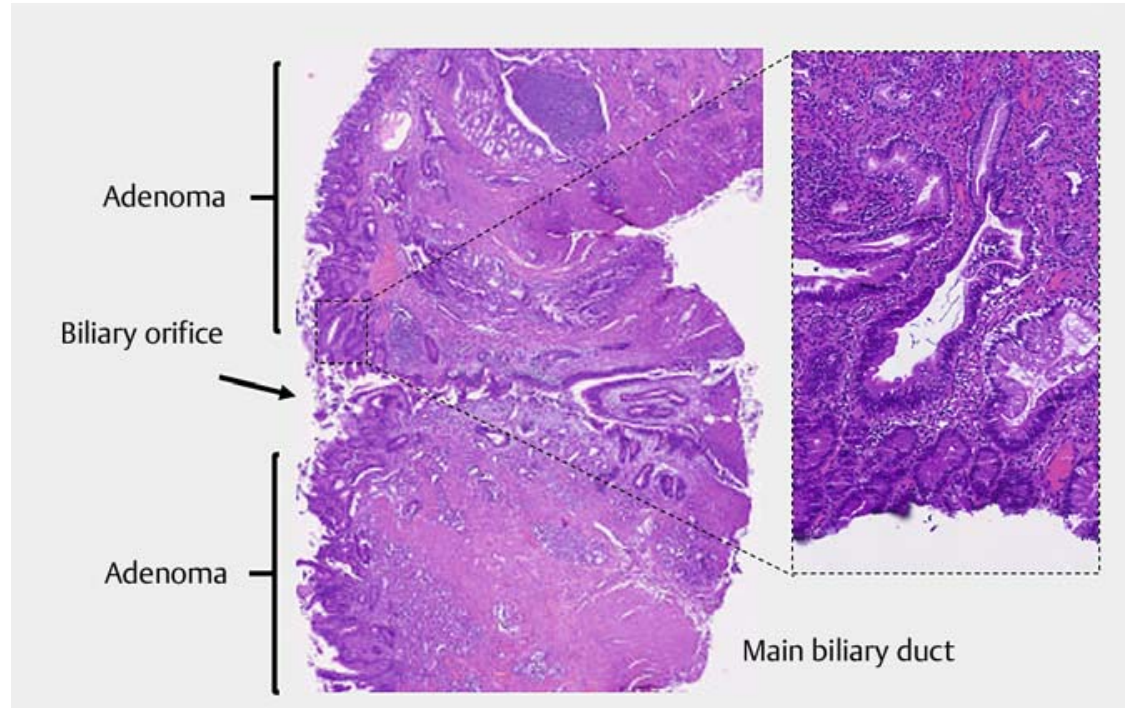

Fig. 4 Histological features of the ampulloma-like resection. Hematoxylin and eosin staining revealed a tubulous adenoma with low-grade dysplasia arising and surrounding the biliary orifice.

References

[1] Todani T, Watanabe Y, Narusue M et al. Congenital bile duct cysts: classification, operative procedures, and review of thirtyseven cases including cancer arising from choledochal cyst. Am J Surg 1977; 134: 263-269

[2] Culetto A, Miranda-Garcia P, Tellechea JI et al. Endoscopic treatment of a choledochocele. Endoscopy 2016; 48: E286

[3] Lobeck IN, Dupree P, Falcone RA et al. The presentation and management of choledochocele (type III choledochal cyst): a 40-year systematic review of the literature. J Pediatr Surg 2017; 52: 644-649

[4] Kim TH, Park JS, Lee SS et al. Carcinoma arising in choledochocele: is choledochocele innocent bystander or culprit? Endoscopy 2002; 34: 675-676
Bibliography

Endoscopy 2022; 54: E47-E48

DOI 10.1055/a-1376-6350

ISSN 0013-726X

published online 5.3.2021

C) 2021. Thieme. All rights reserved.

Georg Thieme Verlag KG, Rüdigerstraße 14, 70469 Stuttgart, Germany

\section{ENDOSCOPY E-VIDEOS}

https://eref.thieme.de/e-videos

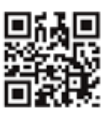

Endoscopy E-Videos is an open access online section, reporting on interesting cases and new techniques in gastroenterological endoscopy. All papers include a high quality video and all contributions are freely accessible online. Processing charges apply (currently EUR 375), discounts and wavers acc. to HINARI are available.

This section has its own submission website at https://mc.manuscriptcentral.com/e-videos 